\title{
AN INNOVATIVE PROJECT TO STRENGTHEN AND IMPROVE THE KNOWLEDGE ACQUISITION IN THE DEGREE IN CHEMISTRY USING E-LEARNING TOOLS
}

\author{
Josep Esteve-Romero ${ }^{1}$, Juan Peris-Vicente ${ }^{2}$, Jaume Albiol-Chiva ${ }^{1}$, Samuel \\ Carda-Broch ${ }^{1}$, María José Ruiz Ángel ${ }^{2}$, Mar Esteve-Amorós ${ }^{2}$, Dolores Yusá- \\ Marco $^{3}$, María Teresa Doménech-Carbó ${ }^{3}$, Pau Esteve-Amorós ${ }^{4}$, Devasish Bose ${ }^{5}$, \\ Abhilasha Durgavanshi ${ }^{5}$ \\ ${ }^{1}$ Universitat Jaume I (SPAIN) \\ ${ }^{2}$ Universitat de València (SPAIN) \\ ${ }^{3}$ Universitat Politècnica de València (SPAIN) \\ ${ }^{4}$ Universitat Politècnica de Catalunya (SPAIN) \\ ${ }^{5}$ Dr. H.S. Gour University (INDIA)
}

\begin{abstract}
The subject "Chemistry II (QU910)" is taught at first academic year (second semester) of the Degree in Chemistry at the University Jaume I. Some of its specific and general competencies are selflearning and writing and oral communication, regarding the main chemical concepts: chemical reactions, elements of the periodic table and calculations of the concentrations of the formed products and the remaining reagents in acid/base, complex, precipitation and redox reactions. We have noticed that $65 \%$ of the students have not studied any chemistry subjects (or only one) in High School or Professional Training before undertaking the Degree in Chemistry. The present project aims firstly to help these students to overcome their lack of background, secondly to compare the academic results of the students with and without previous contact with chemistry and finally, to establish actions to solve this prejudicial situation. This objective was reached by the implementation of a zero course, a course including the basic content of chemistry taught in the last years of High School, the month before the beginning of the first academic year. After the first year, students having attended chemistry before university obtained only $0.75 / 10$ points more than the others. The Virtual Classroom, the emails and tutorial played an important role in the achievement of this zero-course.
\end{abstract}

Keywords: Chemistry; Digital platform; Special needs; Student typology; University.

\section{INTRODUCTION}

The subject "Chemistry II" (QU910) is taught at the second semester of the first academic year in the Degree in Chemistry at the University Jaume I (UJI). Some of its main specific and generic competencies are self-learning and oral and written communication [1], related to the main chemical reactions, the different elements of the periodic table, as well as the calculations of the products formed and the remaining reagents in acid/base, complex, precipitation and redox equilibria. Therefore, the student is requested to resolve by himself several numerical problems and to elaborate and expose and oral presentation face to the other students in a special session. The previous years, we noticed, by means of several questionnaires fulfilled by the students, that nearly $65 \%$ of them do not have taken any Chemistry course, or have only studied only one, in the High School. This represents an important disadvantage for these students, which must make an extra work to learn many basic concepts, content, formula, problem resolution strategies, use of new technologies and programming already known by the other students, and normally not explained by the professor, who assumes that the student have acquired these concepts.

For these reasons, once identified the students in this situation, the professors offer them the possibility to take a zero-course at University level, in which the contents that they have not previously studied and will need are taught, focusing on the most relevant: chemical reactions and equilibria (acid/base, complex, precipitation and redox).

After tackling the important challenge that represents the enhancement of the background of the students, the most efficient approach was via e-mail [2] and Virtual Classroom [3]. Both tools permit a permanent communication, albeit at distance, allowing to the student the learning of basic concepts 
they will need to pass the subject. Another advantage is that the students can work individually anytime, depending on their availability and will, without the need of follow a preset timetable.

In the last years, several tools, elaborated to implement University and non-University learning, have emerged with strength and have been made available for students and lecturers. This has changed the way to access the content and information about the subjects. In addition, it has stimulated the claim of more potent informatics tools [1-4]. The library [5] is adapting to this new situation, through the purchase of more and more electronic books, e-books or e-books [6,7] and less on paper, in order to facilitate more electronic books. All this facilitates and allows work and study 'off campus'. In the Universitat Jaume I (UJI), we work in a Google and Moodle environment, making use of tools such as the Virtual Classroom. Teaching @distance depends on the capacity and speed of the internet, as well as the programs developed for this task. Currently there are various commercial platforms or open access, such as: WebCT [8], eCollege.com [9], among the first one, and Moodle [10] and Whiteboard [11], among the latter. This allows the inclusion of students of diverse needs, as well as for the normal development of teaching during a course [12-17].

A study was done to help students with no or little knowledge in chemistry. Academic results are compared with other students, making use of the tools provided by the UJI: Virtual ClassroomAcademic Information System (SIA), e-mail and the e-tutorials. Students can use these tools @distance, from their home, workplace or any other place where they have WIFI, such as public transport (bus, train), hospitals, clinics, etc., or making use of the smart phones by virtual private network (VPN) [18].

The present work is also part of the UJI Educational Model (2012) 'Sapientia suela libertas est' [19]. Specifically in the section: 2.4. Student support plan, and specifically in the following points: 2.4.1. Program to improve student academic performance, and 2.4.4. Program of access to information resources. It also takes into account the works developed in other nearby universities [20-21] or distant centers such as Google [22-23] via MEL Chemistry VR, which are chemistry topics in the virtual reality environment.

\section{METHODOLOGY}

First, it was requested that those students who had not attended chemistry in the baccalaureate or just did one course, could be volunteers in this study. 12 students requested to participate in the electronic tutorials program that was proposed.

In this study, referred to the subject Chemistry II, Chemistry I was not considered since its contents are mainly of inorganic and organic chemistry, without relation to the chemistry of the equilibria or Chemistry II.

Second, these students passed a test, which is shown in Table 1. They did not have a calculator, since the questions are logical and simple that only requires understanding the basic concepts of chemistry. Each question has a value of 0 (incorrect answer) or 1 (correct). The limit time to complete the test was 15 minutes. The solutions can be seen in Table 2.

Table 1. Initial questionnaire for students of Chemistry II.

Answer the following questions logically, that is, without making any calculations.

\begin{tabular}{r|l}
\hline \hline 1 & An acid has a pKa of 5 and its concentration is $0.1 \mathrm{M}$. What is the approximate $\mathrm{pH} ?$ \\
\hline 2 & $\begin{array}{l}\text { An insoluble compound (MA) has a solubility constant of } 10^{-10} \text { and another one }(\mathrm{MB}) \text { of } 10^{-20} \text {. Which } \\
\text { compound is more soluble? }\end{array}$ \\
\hline 3 & $\begin{array}{l}\text { A metal forms a complex with a ligand with a formation constant of } 10^{+6} \text {. The concentration of the metal } \\
\text { and ligand are } 0.15 \mathrm{M} \text { and } 0.10 \mathrm{M} \text {, respectively. What is the concentration of the complex formed? }\end{array}$ \\
\hline 4 & Is there any relationship between reduction redox potential and equilibrium constant? \\
\hline \hline
\end{tabular}


Table 2. Answers of the questionnaire shown in Table 1.

\begin{tabular}{l|l}
\hline \hline 1 & The approximate $\mathrm{pH}$ will be a little less than 5, which is the $\mathrm{pK}_{\mathrm{a}}$ of the acid. \\
\hline 2 & The most soluble is MA $\left(\mathrm{s}=10^{-5} \mathrm{M}\right)$, while $\mathrm{MB}$ has $\mathrm{s}=10^{-10} \mathrm{M}$. \\
\hline 3 & {$[\mathrm{ML}]=0.1 \mathrm{M}$} \\
\hline 4 & Yes. $\mathrm{K}=10^{+(\mathrm{nE} / 0.059)}$. Note: only indicating yes, the answer is considered as correct \\
\hline \hline
\end{tabular}

A demonstration was made of the contents of the UJI website, which appears in Figure 1 and how to make use of the Virtual Classroom-SIA. Several pages of the UJI were presented, especially those of the library (Figure 2).

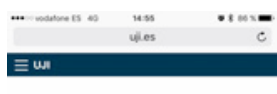

\section{I. U UNIVERSITAT}

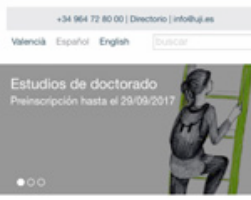

Destacados

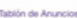

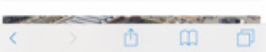

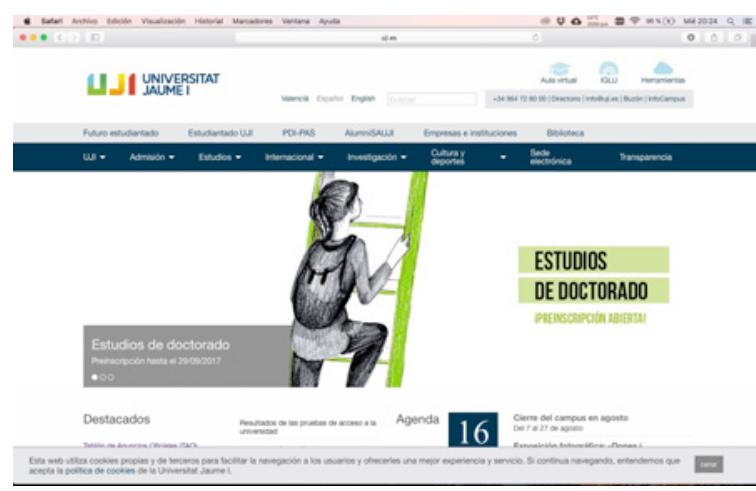

Figure 1. UJI main website, in versions for smartphone and PC.

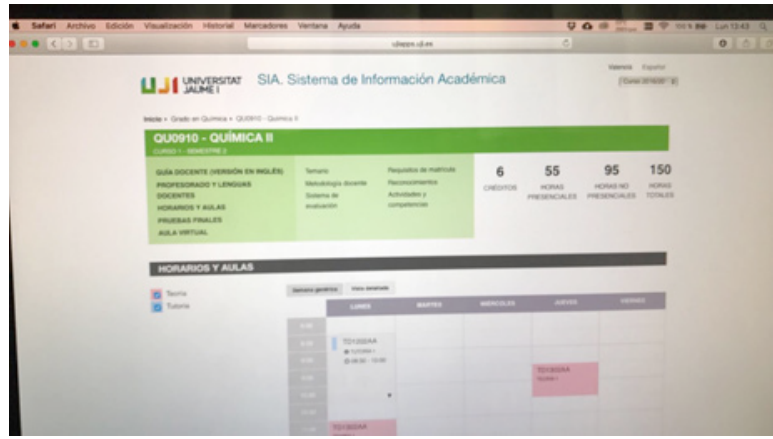

SIA of the subject 910 .

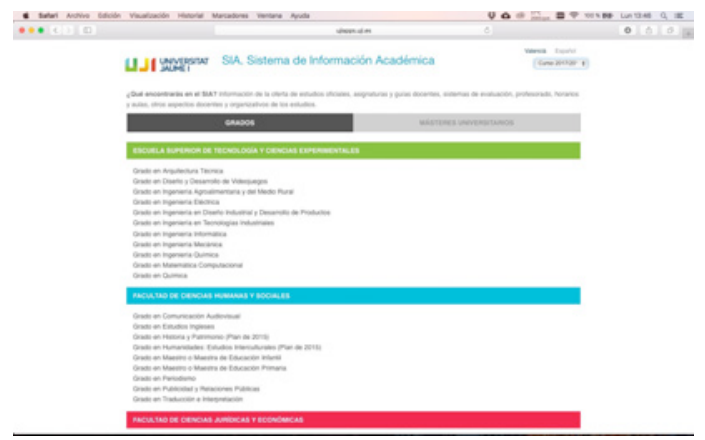

Homepage of the SIA.

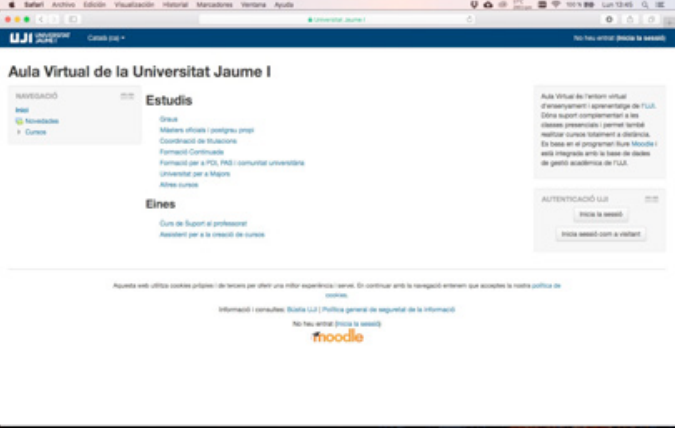

UJI Virtual classroom.

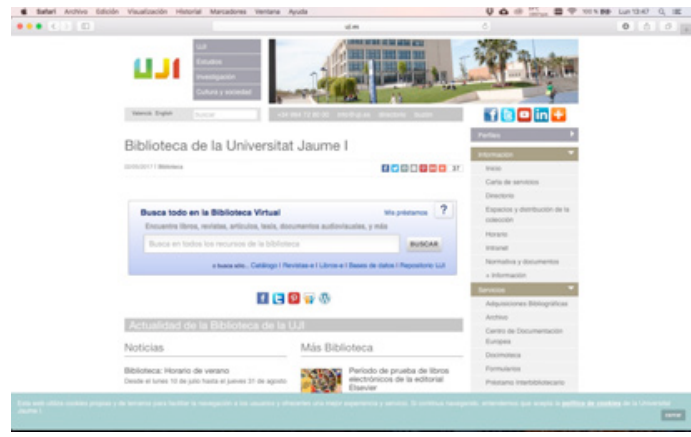

Homepage of the UJI library. 


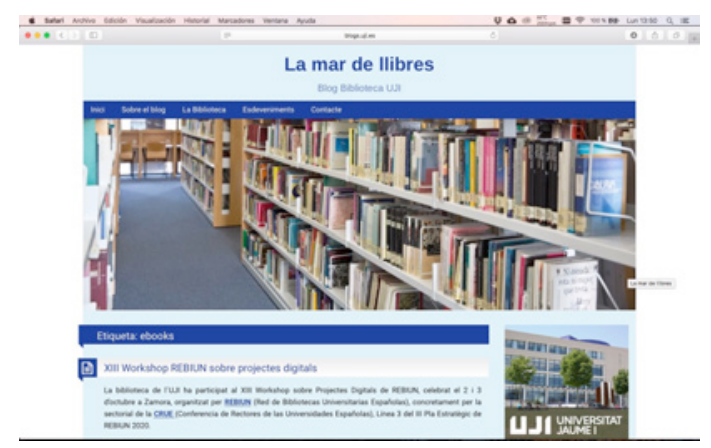

Link to the e-books available for the UJI community.

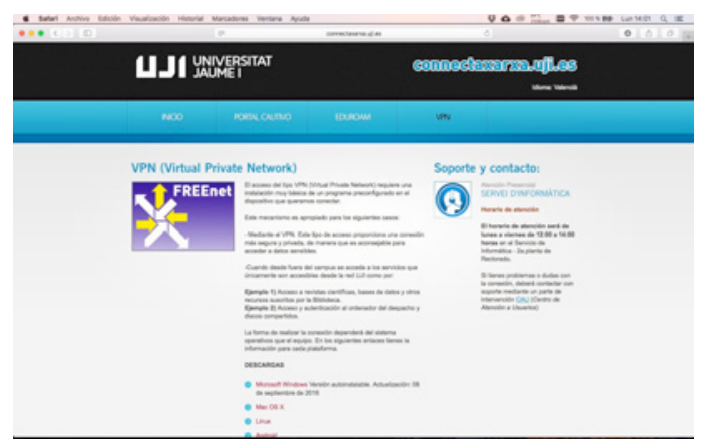

UJl page to download the VPN software.

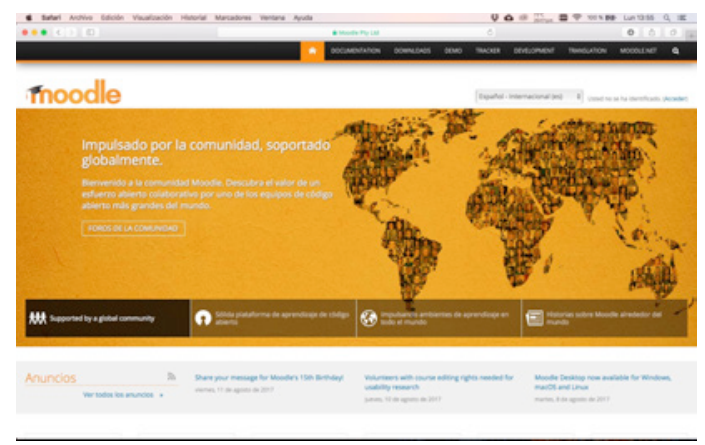

Moodle home page.

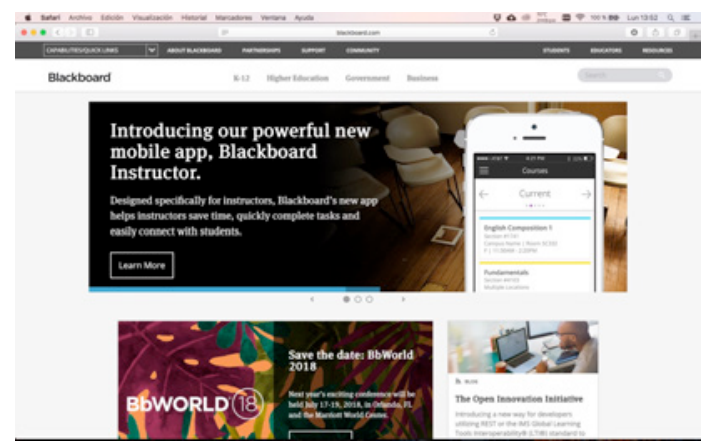

Blackboard.

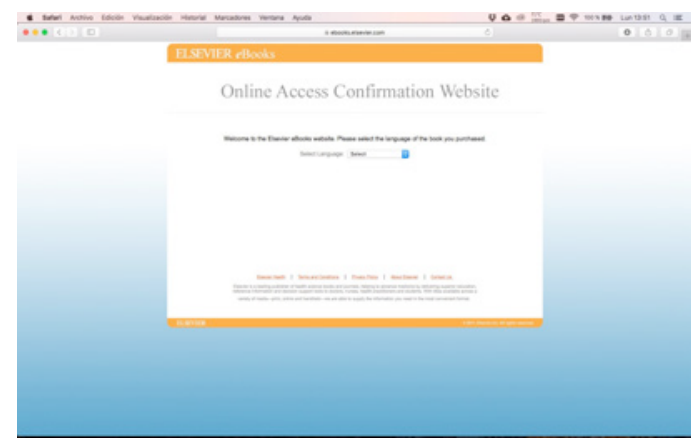

Link to Elsevier e-books, with free access until January 2018.

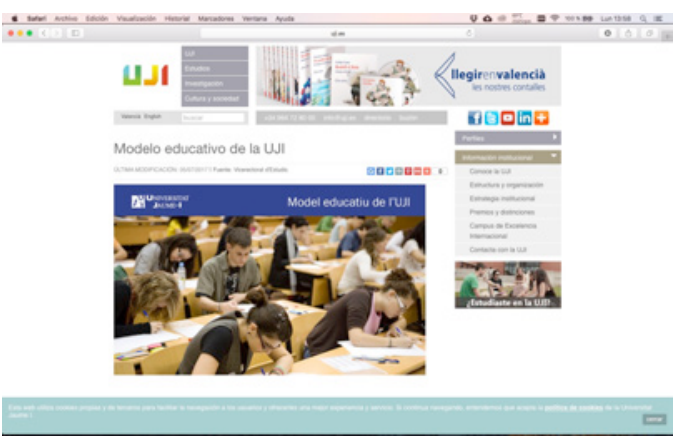

Educational model of the UJI.

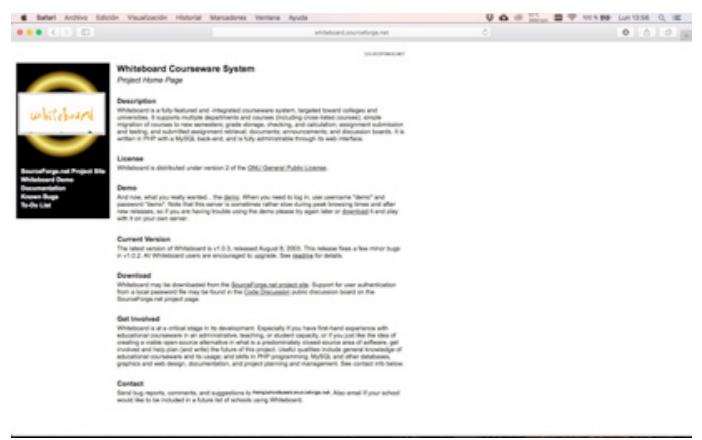

Whiteboard.

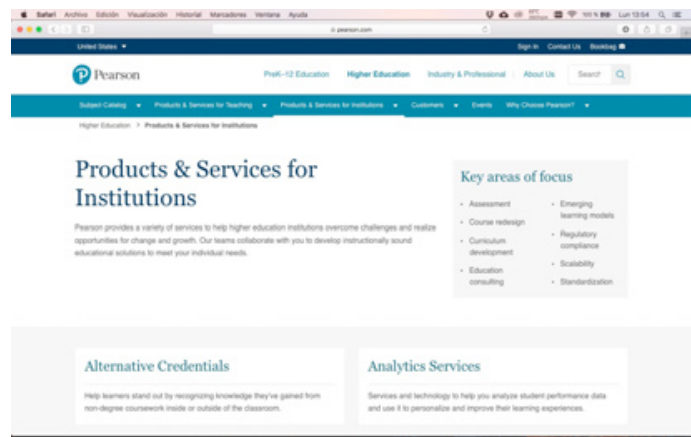

Pearson

Figure 2. Webs of the UJI useful in @distance teaching.

\section{RESULTS}

The 12 students who answered the questionnaire obtained an average score of 2 out of 4 , taking into account the simplicity of the questions. The results are shown in Table 3. Minimum score was 0 and 
the maximum 4. Figure 1 shows the answers of the student who obtained 4/4. Table 2 shows the correct answers.

When the same study was proposed to students who had coursed chemistry at high school, the result was an average grade of 3/4, minimum 2 and maximum 4 . The results are shown in Table 4.

Table 3. Questionnaire score for the 12 students participating in the study (those students had not previously coursed any chemistry subjects).

\begin{tabular}{l|l|l|l|l|l|l|l|l|l|l|l|l}
\hline \hline Student & 1 & 2 & 3 & 4 & 5 & 6 & 7 & 8 & 9 & 10 & 11 & 12 \\
\hline Score & 0 & 0 & 0 & 1 & 2 & 2 & 2 & 2 & 2 & 3 & 3 & 4 \\
\hline \hline
\end{tabular}

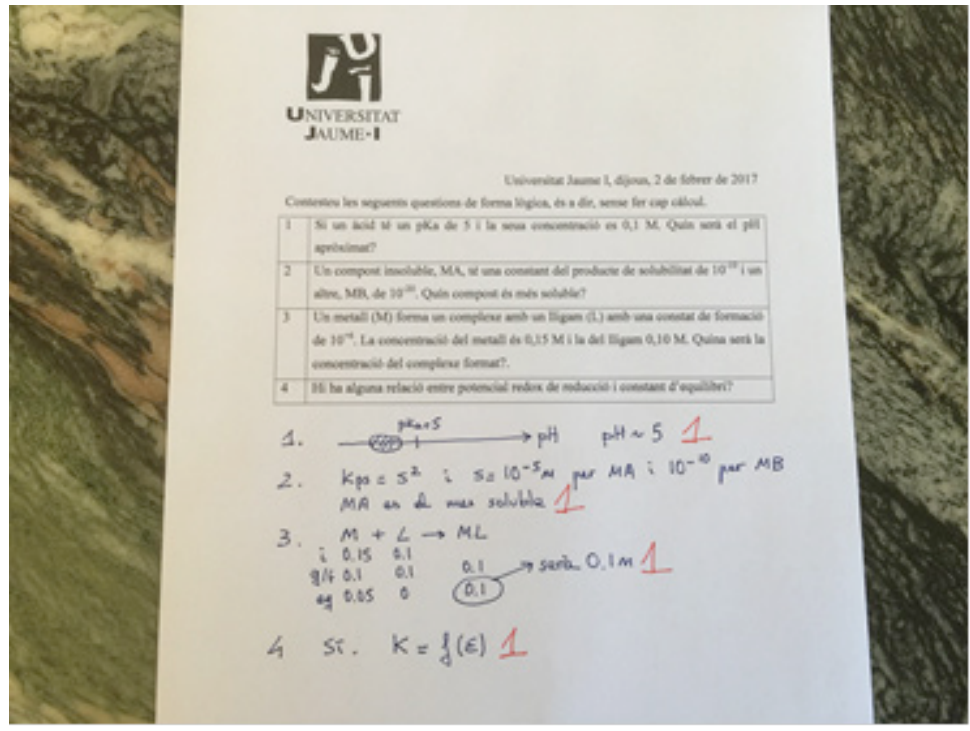

Figure 3. Questionnaire answered by the volunteer student who obtained 4/4 points.

Table 4. Questionnaire scores for the 10 control students (those students had already coursed chemistry subjects).

\begin{tabular}{l|c|c|c|c|c|c|c|c|c|c}
\hline \hline Student & 1 & 2 & 3 & 4 & 5 & 6 & 7 & 8 & 9 & 10 \\
\hline Score & 2 & 2 & 3 & 3 & 3 & 3 & 3 & 4 & 4 & 4 \\
\hline \hline
\end{tabular}

Self-learning materials, e-books, among others, were recommended to the students who participated in this study, as well as scanned material in order to advance in their studies and improve their level in chemistry in the part of chemical equilibria. In addition, a biweekly follow-up was carried out, once each of the topics was finalized. That is, a writing evaluation and also oral questions was made, subject by subject. From the 12 students who started the study, 4 left it. The reasons were: lack of time or having found a job.

With this strategy of using the virtual tools of the UJI (Virtual Classroom, SIA, e-mail, e-books, library, etc.) it was surveyed whether the students with the handicap of not having studied any or just a subject of chemistry during the baccalaureate, they could equalize their level with the students who had completed several subjects in chemistry. The way to prove it was by comparing the grades obtained by the study group and the control group.

Finally, the study group was composed by 8 students until the end and from which the grades were considered. All 8 students succeed, obtaining an average score of 5.65 out of 10 . It must be taken into account that the evaluation of this subject consists of different parts, differently weighted. Thus, on a final grade of 10 , the exam is worth 8 points, the attendance and participation to tutorials 1 point, the delivery of problems 0.5 points, and an oral presentation 0.5 points. 
In the control group formed by 10 students, the average score was $6.4 / 10$, that is, 0.75 points above the study group. This difference is minimal, due to the initial level of both groups. It is clear that the participants, previously in inferiority of conditions, made an effort, using the virtual tools, to level up themselves to the other of the students, and they achieved it.

In the work of Anusha Wijayaratne and Diljit Singh [14], in the sheets 20 to 25, is included a detailed list of the URLs of webs of various universities that do the teaching @distance or 'Open University'. In the case of the UJI, this information is seen in various citations [1-7, 18,19], also for various platforms [8-11] and they are shown in Annex 2. The participating students know and use them, but when they are asked about these tools, they expressed the difficulty that sometimes had in order to access resources from home through VPN and the difficulty of using certain tools, because they offer too many applications when only a few are used.

\section{CONCLUSIONS}

- The study presented here serves to help future students who begin the degree in chemistry at the UJI with the handicap of not having taken any or just one subject of chemistry in the baccalaureate. The virtual tools (Virtual Classroom, SIA, etc.) show to be effective for this purpose.

- Also, the comparison of the final academic results between both groups of students (those who have coursed chemistry subjects and those who did not) are comparable, with only a difference of 0.75 points.

- In this work, the main tools are the Virtual Classroom, e-mail and tutorials

- Students have pointed out the difficulty that sometimes had to access to resources from home via VPN and the difficulty of using certain tools, which can offer too many possibilities or are too powerful for the objectives here raised.

\section{ACKNOWLEDGEMENTS}

The article has been written with the support of the Unitat de Suport Educatiu of the University Jaume I, by projects GIE-Química Bioanalítica, GIE-Innovació Educativa 3431/17 and GIE-Mobilitat 3537/18.

\section{REFERENCES}

[1] http://ujiapps.uji.es/sia/rest/publicacion/2017/estudio/208/asignatura/QU0910. SIA of Chemistry II. Accessed on April 2018.

[2] alumail000000@uji.es. Accessed on September 2017.

[3] https://aulavirtual.uji.es. UJI Virtual Classroom. Accessed on April 2018.

[4] http://ujiapps.uji.es/sia/rest/publicacion/2017, 2017. Main website of SIA. Accessed on April 2018.

[5] https://www.uji.es/serveis/cd/. UJI Library. Accessed on April 2017.

[6] https://jira.uji.es/confluence/display/MANUJI/Espais+cedits. E-books UJI. Accessed on April 2018.

[7] https://ebooks.elsevier.com/ebooks/. Accessed on April 2018.

[8] http://www.blackboard.com/company. Accessed on April 2018.

[9] http://www.ecollege.com/index.learn. Accessed on April 2018.

[10] http://moodle.org. Accessed on April 2018.

[11] http://whiteboard.sourceforge.net. Accessed on April 2018.

[12] F.A. Vitoriano, V.L.G. Teles, I.M. Rizzatti, R.C. Pessoa de Lima, "Promoting Inclusive Chemistry Teaching by Developing an Accessible Thermometer for Students with Visual Disabilities", J. Chem. Educ., vol. 93, pp. 2046-2051, 2016, DOI: 10.1021/acs.jchemed.6b00162. 
[13] M. Kahveci, M. Orgill (eds.), Affective Dimensions in Chemistry Education. Berlin Heidelberg/Germany, Springer-Verlag, 2015.

[14] A. Wijayaratne, D. Singh, "Is there space in the cyberspace for distance learners with special needs in Asia? A review of the level of Web accessibility of institutional and library homepages of AAOU members", Int. Inf. Libr. Rev., vol 42, 1-34, 2010.

[15] Madhya Pradesh Bhoj Open University, India. http://www.bhojvirtualuniversity.com/. Accessed on April 2018.

[16] K. Golub, N. Lazic, Accessibility of public library web sites. http://koraljka.info/publ/2002LIDA.pdf, 2001. Accessed on April 2018.

[17] M.T. Graells, M.R. Ribera, A.D., Sule, Accessibility level of websites in the Spanish universities. http://redc.revistas.csic.es/index.php/redc/article/viewFile/131/185, 2003. Accessed on April 2018.

[18] connectaxarxa.uji.es. Download website of VPN. Accessed on April 2018.

[19] https://documents.uji.es/alfresco/d/d/workspace/SpacesStore/a92a5c90-eb2c-42e9-acc7$7 \mathrm{c09d4a7d657/modeduc-v.pdf?guest=true.} \mathrm{Download} \mathrm{website} \mathrm{of} \mathrm{the} \mathrm{Educational} \mathrm{Model} \mathrm{of} \mathrm{UJI.}$ Accessed on April 2017.

[20] https://www.uv.es/upd/doc/normativas/uv/UV_pla_eaccessibilitat.pdf. Accessed on April 2018.

[21] http://www.url.edu/sites/default/files/unidiscat_2.pdf. Accessed on April 2018.

[22] V. Philippov, "Daydreaming in the classroom", The Analytical Scientist. July 2017, pp. 10.

[23] https://melscience.com/vr. Accessed on April 2018. 